\title{
Aplikasi Model Persamaan Struktural Pada Program R (Studi Kasus Data Pengukuran Kecerdasan)
}

\author{
Achi Rinaldi \\ IAIN Raden Intan Lampung: achi_rinaldi@yahoo.uk
}

Submitted : 17-03-2015, Revised : 14-04-2015, Accepted : 16-06-2015

\begin{abstract}
Structural Equation Model (SEM) was known as powerfull and popular multivariate analysis technique. It provides a comprehensive method for the quantification and testing of theories. The ability of this model is to test model with multiple dependent that more powerfull than multiple regression, it's also can make some simultaneously model in one form. Data was used from Holzinger and Swineford that measured intellegence in several indicator. This model was lack of form and performance that can be showed in value of Chi-square. Akaike Information Criterion (AIC) and Chi-square value for specificly in block "male" was less than "female", so the result gave structural model for block male was better than female.
\end{abstract}

Keyword: Structural Equation Model

\begin{abstract}
Abstrak
Structural Equation Model (SEM) dikenal sebagai teknik analisis multivariat yang kuat dan populer. Ini menyediakan metode komprehensif untuk kuantifikasi dan pengujian teori. Kemampuan model ini adalah untuk menguji model dengan beberapa dependensi yang lebih kuat daripada regresi berganda, namun juga dapat membuat beberapa model secara simultan dalam satu bentuk. Data digunakan dari Holzinger dan Swineford yang mengukur intellegence pada beberapa indikator. Model ini kurang bentuk dan kinerjanya yang bisa ditunjukkan nilai Chi-square. Kriteria Informasi Akaike (AIC) dan Chi-kuadrat untuk secara spesifik di blok "jantan" kurang dari "betina", sehingga hasilnya memberikan model struktural untuk blok jantan lebih baik dari pada betina.
\end{abstract}

Kata Kunci: Model Persamaan Struktural

\section{PENDAHULUAN}

Dalam kehidupan sehari-hari, seringkali dijumpai hubungan antara suatu variabel dengan satu atau lebih variabel lain. Di dalam bidang pertanian sebagai contoh, dosis dan jenis pupuk yang diberikan berhubungan dengan hasil pertanian yang diperoleh, jumlah pakan yang diberikan pada ternak berhubungan dengan berat badannya, dan sebagainya. Secara umum ada dua macam hubungan antara dua atau lebih variabel, yaitu bentuk hubungan dan keeratan hubungan. Bila ingin mengetahui bentuk hubungan dua variabel 
atau lebih, digunakan analisis regresi. Bila ingin melihat keeratan hubungan, digunakan analisis korelasi.

Analisis regresi adalah teknik statistika yang berguna untuk memeriksa dan memodelkan hubungan diantara variabel-variabel. Penerapannya dapat dijumpai secara luas di banyak bidang seperti teknik, ekonomi, manajemen, ilmu-ilmu biologi, ilmu-ilmu sosial, dan ilmu-ilmu pertanian. Pada saat ini, analisis regresi berguna dalam menelaah hubungan dua variabel atau lebih, dan terutama untuk menelusuri pola hubungan yang modelnya belum diketahui dengan sempurna, sehingga dalam penerapannya lebih bersifat eksploratif. Analisis regresi dikelompokkan dari mulai yang paling sederhana sampai yang paling rumit, tergantung tujuan yang berlandaskan pengetahuan atau teori sementara, bukan asal ditentukan saja.

Jika tujuan analisis adalah untuk melihat hubungan kausalitas antara kejadian satu dan kejadian lain, maka analisis yang digunakan adalah Analisis Path. Hubungan kausalitas yang ingin dilihat berupa besar hubungan langsung maupun tidak langsung. Pendekatan analisis yang digunakan pada analisis path tidak berbeda dengan analisis regresi ganda. Hanya sedikit berbeda pada perhitungan pendugaan koefisiennya. Pada saat ini jenis analisis ini berkembang pada bidang sosial, seperti psikologi, pendidikan, dan lain-lain.

Teknik analisis jalur, yang dikembangkan oleh Sewal Wright di tahun 1934, sebenarnya merupakan pengembangan korelasi yang diurai menjadi beberapa interpretasi akibat yang ditimbulkannya. Lebih lanjut, analisis jalur mempunyai kedekatan dengan regresi berganda; atau dengan kata lain, regresi berganda merupakan bentuk khusus dari analisis jalur. Teknik ini juga dikenal sebagai model sebab-akibat (causing modeling). Penamaan ini didasarkan pada alasan yang bahwa analisis jalur memungkinkan pengguna dapat menguji proposisi teoritis mengenai hubungan sebab dan akibat tanpa memanipulasi variabelvariabel. Asumsi dasar model ini ialah beberapa variabel sebenarnya mempunyai hubungan yang sangat dekat satu dengan lainnya. Secara definisi analisis jalur ialah suatu teknik untuk menganalisis hubungan sebab akibat yang tejadi pada regresi berganda jika variabel bebasnya mempengaruhi variabel tergantung tidak hanya secara langsung tetapi juga secara tidak langsung". (Robert D. Retherford 1993). Analisis jalur juga merupakan pengembangan langsung bentuk regresi berganda dengan tujuan untuk memberikan estimasi tingkat kepentingan (magnitude) dan signifikansi (significance) hubungan sebab akibat hipotetikal dalam seperangakat variabel." (Paul Webley 1997). Secara matematik Analisis Jalur mengikuti pola Model Struktural. Dalam perkembangannya saat ini analisis jalur diperluas dan diperdalam kedalam bentuk analisis "Structural Equation Modeling" atau dikenal dengan singkatan SEM.

Structural Equation Modeling atau Model Persamaan Struktural yang biasa disingkat dengan SEM merupakan pengembangan dari analisis jalur yang telah ada sebelumnya, dalam SEM terdapat dua komponen yaitu:

1. Hubungan antar peubah laten yang digambarkan dalam "Latent Variable Model" (Model Peubah Laten).

2. Hubungan antara peubah laten dan peubah amatan yang digambarkan dalam "Measurement model" (Model Pengukuran).

Peubah Laten merupakan suatu peubah yang tidak bisa diukur secara langsung dan bergantung pada suatu indikator pengukuran. Contoh peubah laten dapat dilihat pada 
Gambar 1, dimana peubah intelligence tidak dapat diukur secara langsung, melainkan melalui peubah indikator berupa tes 1 sampai dengan tes 5 .

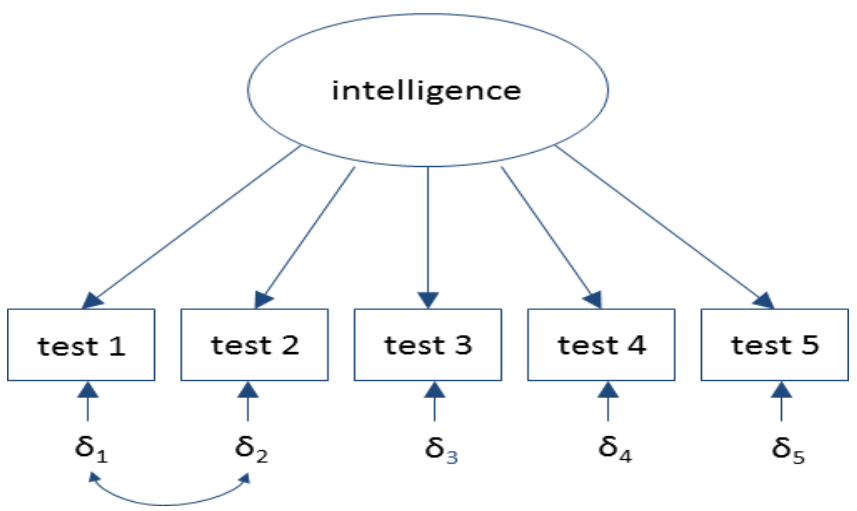

Gambar 1 Peubah Laten Intelligence

Persamaan Struktural untuk Peubah Laten dapat ditulis sebagai:

Dimana $\boldsymbol{\eta}=\mathbf{B} \boldsymbol{\eta}+\boldsymbol{\Gamma} \boldsymbol{\xi}+\boldsymbol{\zeta}$

$\eta=$ vektor dari peubah laten endogen

$\xi=$ vektor dari peubah laten eksogen

$\zeta=$ vektor dari gangguan

$B=$ matriks koefisien utk $\eta$ pada pengaruh $\eta$

$\Gamma=$ matriks koefisien utk $\xi$ pada pengaruh $\eta$

Adapun asumsi dari Persamaan Struktural untuk Peubah Laten adalah:

1. $E(\eta)=0$,

2. $E(\xi)=0$,

3. $E(\zeta)=0$,

4. $\xi$ dan $\zeta$ tidak berkorelasi,

5. Matriks (I-B) nonsingular

Persamaan untuk Model Pengukuran dapat ditulis sebagai:

$$
\begin{aligned}
& \mathbf{x}=\Lambda_{\mathbf{x}} \boldsymbol{\xi}+\boldsymbol{\delta} \\
& \mathbf{y}=\boldsymbol{\Lambda}_{\mathbf{y}} \boldsymbol{\eta}+\boldsymbol{\varepsilon}
\end{aligned}
$$

dimana:

$$
\begin{aligned}
& x=\text { indikator dari } \xi \\
& \Lambda_{x}=\text { loading faktor dari } \xi \\
& y=\text { indikator dari } \eta \\
& \Lambda_{y}=\text { loading faktor dari } \eta \\
& \delta=\text { galat pengukuran dari } x \\
& \varepsilon=\text { galat pengukuran dari } y
\end{aligned}
$$

Asumsi:

1. $E(\eta)=0$

2. $E(\xi)=0$

3. $E(\varepsilon)=0$ 
4. $\mathrm{E}(\delta)=0$

5. $\varepsilon, \eta, \xi$ dan $\delta$ tidak berkorelasi

\section{Analisis Jalur}

Hubungan-hubungan yang ada dalam Model Persamaan Struktural (SEM), baik itu model peubah laten, maupun model peubah pengukuran dapat dengan baik digambarkan oleh diagram jalur. Untuk simbol-simbol dalam analisis jalur dijabarkan sebagai berikut:

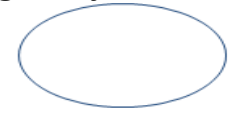

Peubah laten, faktor, constructs

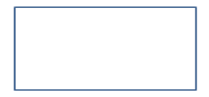

Peubah amatan, ukuran, indikator,

peubah manifest

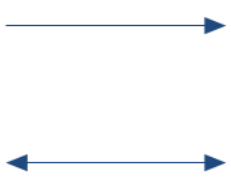

Arah pengaruh, hubungan dari satu peubah ke

peubah yang lain

Asosiasi dalam model

Adapun contoh dari diagram jalur dapat dilihat pada gambar 2 yang terdapat dalam Bollen, K A (1989) mengenai industrialisasi dan demokrasi.

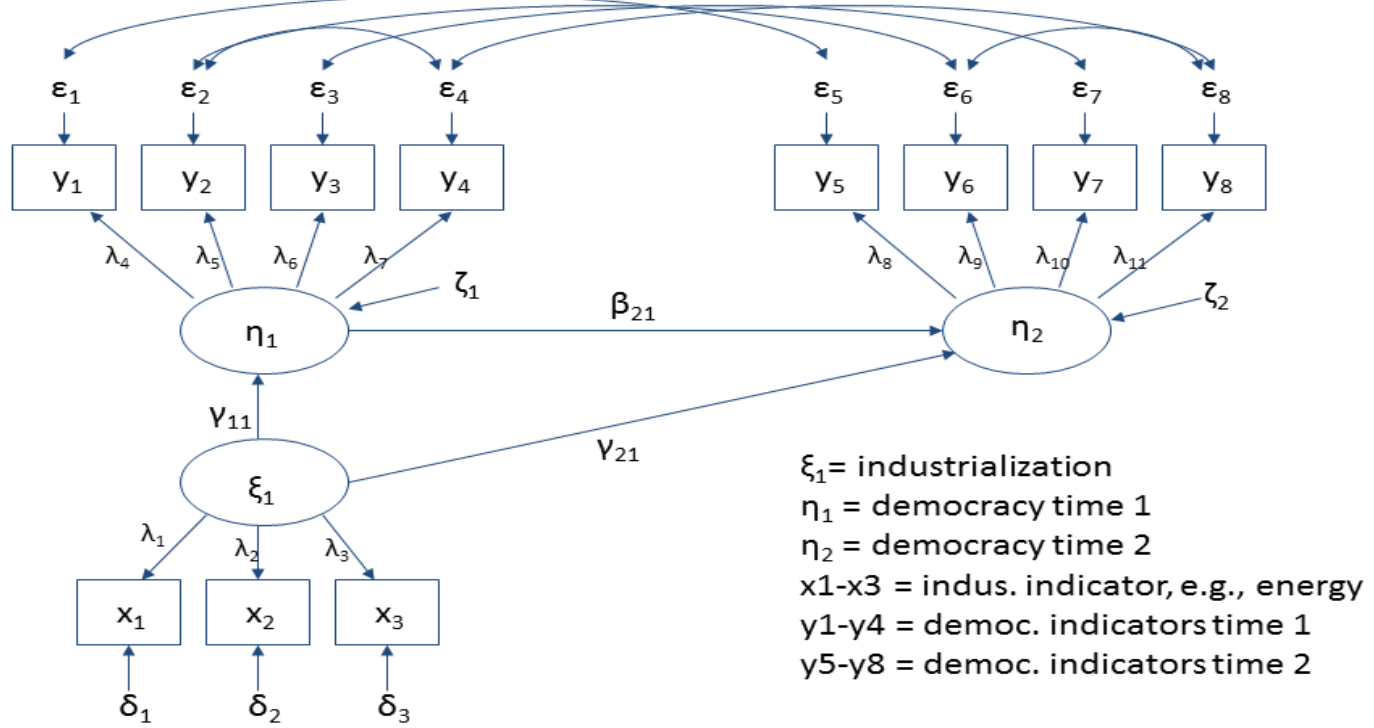

Gambar 2 Contoh Diagram Jalur

\section{METODE PENELITIAN}

Tulisan ini merupakan studi pustaka yang merupakan telaah dari literatur. Sebagimana di sampaikan (M. Nazir, 2003:27) bahwa teknik pengumpulan data dengan mengadakan studi penelahaan terhadap buku-buku literatur-literatur, catatan-catatan, dan laporan-laporan yang ada hubungannya dengan masalah yang dipecahkan. Setelah informasi yang relevan ditemukan, peneliti kemudian "mereview" dan menyusun bahan pustaka 
sesuai dengan urutan kepentingan dab relevansinya dengan masalah yang sedang diteliti. Bahan-bahan informasi yang diperoleh kemudian dibaca, dicatat, diatur, dan ditulis kembali.

\section{HASIL PENELITIAN DAN PEMBAHASAN}

\section{Aplikasi Model Persamaan Struktural (SEM)}

Data berasal dari Holzinger dan Swineford (1939) yang berisi 26 jenis tes dengan ukuran sampel sebanyak 301 . Studi yang terdiri dari 26 jenis tes ini untuk mengukur peubah laten, yaitu: kemampuan spasial, verbal, mental speed, memori,dan kemampuan matematika. Dalam ilmu pendidikan memang kemampuan kognitif secara spesifik, seperti kemampuan penalaran, verbal, dan memori merupakan peubah yang tidak dapat diukur secara langsung Adapun indikator masing-masing peubah laten, pertama peubah spasial dimana indikatornya adalah: visual, cubes, paper, flags, paperrev, dan flagssub. Peubah verbal diindikasikan oleh: general, paragrap, sentence, wordc, dan wordm. Untuk indikator mental speed, yaitu: addition, code, counting, dan straight. Memori diukur dari: wordr, numberr, figurer, object, numberf, dan figurew. Kemampuan matematika diukur dari deduct, numeric, problemr, series, dan arithmet. Adapun peubah yang diamati sebanyak 32 buah dan dapat dilihat dalam Tabel 2.

Tabel 1. Deskripsi Peubah dalam Penelitian

\begin{tabular}{|c|l|l|}
\hline No & \multicolumn{1}{|c|}{ Peubah } & \multicolumn{1}{c|}{ Keterangan } \\
\hline 1 & Id & nomor identitas responden \\
\hline 2 & Gender & tingkatan sekolah responden \\
\hline 3 & Grade & umur dalam tahun \\
\hline 4 & Agey & umur dalam bulan \\
\hline 5 & Agem & asal sekolah \\
\hline 6 & School & skor uji visual (test 1) \\
\hline 7 & Visual & skor uji kubus (test 2) \\
\hline 8 & Cubes & skor uji paper (test 3) \\
\hline 9 & Paper & skor uji lozenges test (test 4) \\
\hline 10 & Flags & skor uji pengetahuan umum (test 5) \\
\hline 11 & General & skor uji paragrap (test 6) \\
\hline 12 & Paragrap & skor uji kalimat (test 7) \\
\hline 13 & Sentence & skor uji klasifikasi kata (test 8) \\
\hline 14 & Wordc & skor uji makna kata (test 9) \\
\hline 15 & Wordm & skor dari uji add (test 10) \\
\hline 16 & Addition & skor uji sandi (test 11) \\
\hline 17 & Code & skor uji berhitung (test 12) \\
\hline 18 & Counting & skor uji garis (test 13) \\
\hline 19 & Straight & skor uji pengenalan kata (test 14) \\
\hline 20 & Wordr & skor uji pengenalan angka (test 15) \\
\hline 21 & Numberr & skor uji pengenalan gambar (test 16) \\
\hline 22 & Figurer & skor dari object-number (test 17) \\
\hline 23 & Object & skor dari number-figure (test 18) \\
\hline 24 & Numberf & \\
\hline & & \\
\hline
\end{tabular}




\begin{tabular}{|l|l|l|}
\hline No & \multicolumn{1}{|c|}{ Peubah } & \multicolumn{1}{c|}{ Keterangan } \\
\hline 25 & Figurew & skor dari figure-word (test 19) \\
\hline 26 & Deduct & skor uji deduksi (test 20) \\
\hline 27 & Numeric & skor uji puzzle (test 21) \\
\hline 28 & Problemr & skor uji konstruksi masalah (test 22) \\
\hline 29 & Series & skor uji series (test 23) \\
\hline 30 & Arithmet & skor dari Woody-McCall form I (test 24) \\
\hline 31 & Paperrev & skor uji paper (test 25) \\
\hline 32 & Flagssub & skor uji flag (test 26) \\
\hline
\end{tabular}

Model persamaan struktural dari data Holzinger dan Swineford yang digunakan dapat dilihat dalam gambar 3. Dalam model awal tersebut dapat dilihat bahwa semua peubah laten, yaitu: kemampuan spatial, verbal, memory dan math memiliki hubungan dua arah yang saling mempengaruhi.

Adapun perangkat lunak yang digunakan untuk membangun model persamaan struktural dari data tersebut adalah program $\mathrm{R}$ dengan paket-paket yang harus terpenuhi, seperti paket "sem" dan "MBESS".

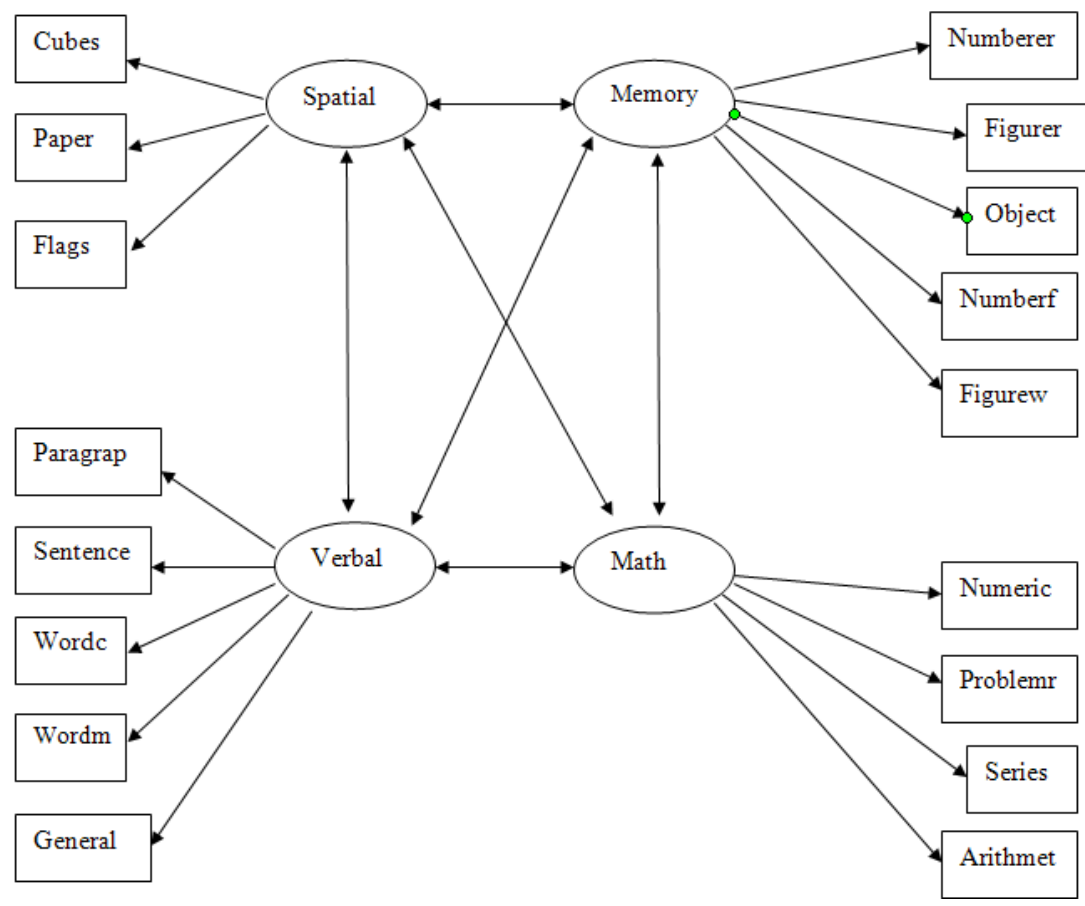

\section{Gambar 3 Model Persamaan Struktural Data Holzinger dan Swineford}

Langkah-langkah dalam membangun model persamaan struktural dalam program, yaitu pertama-tama menginput data atau memanggil data dengan sintaksnya sebagai berikut

$>$ library(MBESS) \# for data

$>$ data(HS.data)

$>$ HS.data 
Selanjutnya peubah laten yang ada dilakukan Confirmatory Factor Analysis:

$>$ mod.hs <- cfa()

Model persamaan struktural dibagi menjadi dua kelompok berdasarkan peubah gender, yaitu Male (laki-laki) dan Female (perempuan):

$>$ mod.mg <- multigroupModel(mod.hs, groups=c("Female", "Male"))

Kemudian dilanjutkan dengan memasukkan peubah amatan ke dalam model persamaan struktural:

> sem.mg <- sem(mod.mg, data=HS.data, group="Gender",

formula $=\sim$ visual + cubes + paper + flags +

general + paragrap + sentence + wordc + wordm +

wordr + numberr + figurer + object + numberf + figurew )

$>$ summary(sem.mg)

Output yang dihasilkan oleh program $\mathrm{R}$ adalah sebagai berikut:

Model Chisquare $=425.2162 \mathrm{Df}=328 \operatorname{Pr}(>$ Chisq $)=0.0002326229$

Chisquare (null model) $=2611.375 \mathrm{Df}=380$

AIC $=609.2162$

$\mathrm{BIC}=-1446.716$

Iterations: initial fits, 447388 final fit, 1

Gender: Female

Model Chisquare $=213.3631$ Df $=164 \operatorname{Pr}(>$ Chisq $)=0.005736491$

$A I C=305.3631$

$B I C=-613.7586$

Normalized Residuals

Min. 1stQu. Median Mean 3rd Qu. Max.

$-2.3490000-0.5168000-0.0000390-0.00048040 .45980002 .6300000$

R-square for Endogenous Variables

visual cubes paper flags general paragrapsentence wordc

$\begin{array}{llllllll}0.5695 & 0.2999 & 0.2708 & 0.3648 & 0.7292 & 0.6853 & 0.7332 & 0.5910\end{array}$

wordm wordr numberr figurer object numberf figurew deduct

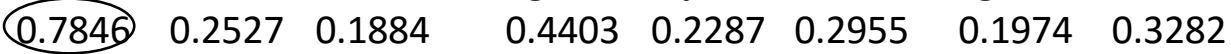

numeric problemr series arithmet

$\begin{array}{llll}0.3618 & 0.5154 & 0.6391 & 0.4393\end{array}$

Secara umum model yang dibangun memang belum sepenuhnya baik, hal ini terlihat dari besarnya Chisquare dan kecilnya nilai $p$-value. Dilihat dari R-square untuk peubah endogen, jika kita ambil nilai di atas $70 \%$ maka peubah yang sudah memenuhi besarnya keragaman tersebut adalah: general, sentence, dan wordm yang merupakan indikator dari peubah "verbal". Ini menandakan peubah tersebut sudah cukup baik dapat menerangkan keragaman peubah endogen. Sehingga bisa dikatakan untuk peubah laten verbal, maka indikator-indikatornya sudah dapat menerangkan secara baik dibandingkan peubah laten lain, yaitu: spatial, memory dan math. 
Selanjutnya dilakukan pendugaan koefisien parameter, baik dalam model peubah laten, maupun model pengukuran.

Parameter Estimates

lam[cubes:spatial].Female

Estimate Std Error $z$ value $\quad \operatorname{Pr}(>|z|)$

lam[paper:spatial].Female

$0.43271120 .072315655 .9836452 .181985 \mathrm{e}-09$

lam[flags:spatial].Female

$0.26361980 .046246225 .7003531 .195594 \mathrm{e}-08$

$0.92809730 .14159896 \quad 6.5544085 .586313 \mathrm{e}-11$

lam[paragrap:verbal].Female

$0.2889147 \quad 0.0223234412 .9422102 .600394 \mathrm{e}-38$

lam[sentence:verbal].Female $0.43943010 .0320509113 .7103798 .799645 \mathrm{e}-43$

lam[wordc:verbal].Female $\quad 0.42087220 .0366308111 .4895701 .488515 \mathrm{e}-30$

lam[wordm:verbal].Female $0.68254430 .0469077014 .5507935 .772987 e-48$

lam[numberr:memory].Female $0.6260743 \quad 0.16104158 \quad 3.887657 \quad 1.012167 e-04$

lam[figurer:memory].Female $1.0507894 \quad 0.212916704 .9352138 .006316 \mathrm{e}-07$

lam[object:memory].Female $\quad 0.46960290 .113280894 .1454733 .391123 e-05$

lam[numberf:memory].Female $0.47030850 .105010994 .4786607 .511304 \mathrm{e}-06$

lam[figurew:memory].Female $0.3679700 \quad 0.09315642 \quad 3.9500237 .814378 \mathrm{e}-05$

lam[numeric:math].Female $\quad 0.29671950 .049396706 .0068691 .891396 \mathrm{e}-09$

lam[problemr:math].Female $0.64534540 .09531945 \quad 6.7703431 .284773 \mathrm{e}-11$

lam[series:math].Female $\quad 0.7634494 \quad 0.10569037 \quad 7.2234525 .068417 \mathrm{e}-13$

lam[arithmet:math].Female $0.33792070 .05258627 \quad 6.426027 \quad 1.309824 \mathrm{e}-10$

V[spatial].Female

$29.9491756 .184449384 .8426581 .281135 \mathrm{e}-06$

V[verbal].Female

$105.8476016 .260278316 .5095827 .536038 \mathrm{e}-11$

$\mathrm{V}$ [memory].Female

$\mathrm{V}$ [math].Female

$25.5800208 .881316072 .8802063 .974153 \mathrm{e}-03$

C[spatial,verbal].Female

C[spatial,memory].Female

C[spatial,math].Female

$94.85253525 .535052463 .7146012 .035245 \mathrm{e}-04$

$27.8515096 .32472944 \quad 4.4035891 .064745 \mathrm{e}-05$

$\begin{array}{llll}18.3789258 & 4.60105886 & 3.994499 & 6.483115 \mathrm{e}-05\end{array}$

$\begin{array}{llll}42.2964590 & 8.53523438 & 4.955512 & 7.213996 \mathrm{e}-07\end{array}$

C[verbal,memory].Female

C[verbal, math].Female

$24.42778136 .807774783 .5882183 .329456 \mathrm{e}-04$

$\mathrm{C}$ [memory, math].Female

V[visual].Female

$\mathrm{V}$ [cubes].Female

V[paper].Female

V[flags].Female

V[general].Female

$\mathrm{V}$ [paragrap].Female

$85.018351315 .624560955 .4413275 .288502 \mathrm{e}-08$

32.11005298 .493264033 .780649 1.564199e-04

$22.6436883 \quad 3.955129575 .7251441 .033457 \mathrm{e}-08$

$13.09086961 .671884967 .8300064 .878460 \mathrm{e}-15$

$\begin{array}{llll}5.6037941 & 0.70413560 & 7.958402 & 1.742756 \mathrm{e}-15\end{array}$

$44.92635855 .992642477 .4969206 .533505 \mathrm{e}-14$

$39.30176535 .558962097 .0699831 .549531 \mathrm{e}-12$

$\begin{array}{llll}4.0581415 & 0.54823573 & 7.402184 & 1.339632 \mathrm{e}-13\end{array}$

$\begin{array}{llll}7.4389798 & 1.05743204 & 7.034948 & 1.993349 \mathrm{e}-12\end{array}$

$12.97679551 .648894147 .8699993 .546436 \mathrm{e}-15$

$13.53725852 .094420906 .4634851 .023185 \mathrm{e}-10$

$75.6442760 \quad 9.717666007 .7842027 .015454 \mathrm{e}-15$

$43.18568525 .332971848 .0978655 .593216 \mathrm{e}-16$

Untuk output yang dihasilkan dari pendugaan parameter, secara umum menghasilkan nilai parameter yang signifikan, ditandai dari nilai $p$-value yang $<0.05$. Hubungan antar peubah laten, dapat dilihat dari nilai dugaan kovarian, dimana nilai kovarian tertinggi yaitu 
antara peubah verbal dan math, sedangkan kovarian terkecil adalah kovarian antara peubah memori dan spatial. Sehingga dapat dikatakan bahwa peubah math dan verbal memang cukup kuat saling mempengaruhi dibanding peubah lainnya.

Bentuk diagram jalur dari persamaan model struktural dalam program $\mathrm{R}$ memang tidak berbentuk gambar seperti dalam LISREL, tapi cukup jelas dengan melihat bentuk anak panah dan arah yang dihasilkan dalam output.

lam[cubes:spatial].Female

lam[paper:spatial].Female

lam[flags:spatial].Female

lam[paragrap:verbal].Female

lam[sentence:verbal].Female

lam[wordc:verbal].Female

lam[wordm:verbal].Female

cubes <--- spatial

paper <--- spatial

flags <--- spatial

paragrap <--- verbal

sentence $<---$ verbal

lam[numberr:memory]. Female numberr <--- memory

lam[figurer:memory].Female figurer <--- memory

lam[object:memory].Female object <--- memory

lam[numberf:memory].Female numberf <--- memory

lam[figurew:memory].Female figurew <--- memory

lam[numeric:math].Female numeric <--- math

lam[problemr:math].Female problemr <--- math

lam[series:math].Female

lam[arithmet:math].Female

$\mathrm{V}$ [spatial].Female

V[verbal].Female

$\mathrm{V}$ [memory].Female

$\mathrm{V}$ [math].Female

C[spatial,verbal].Female

C[spatial,memory].Female

C[spatial,math].Female

C[verbal,memory].Female

C[verbal,math].Female

$C$ [memory,math].Female

V[visual].Female

$\mathrm{V}$ [cubes].Female

$\mathrm{V}$ [paper].Female

V[flags].Female

V[general].Female

$\checkmark$ [paragrap].Female

$\mathrm{V}$ [sentence].Female

$\mathrm{V}[$ wordc].Female

V[wordm].Female

V[wordr].Female

$V$ [numberr].Female series <--- math

arithmet <--- math

spatial <--> spatial

verbal $<-->$ verbal

memory <--> memory

math <--> math

verbal <--> spatial

memory <--> spatial

math <--> spatial

memory <--> verbal

math <--> verbal

math <--> memory

visual $<-->$ visual

cubes <--> cubes

paper <--> paper

flags <--> flags

general <--> general

paragrap $<-->$ paragrap

sentence $<-->$ sentence

wordc <--> wordc

wordm $<-->$ wordm

wordr <--> wordr

numberr <--> numberr 
Hubungan satu arah ditandai dengan lambang "<---" atau " -->", arahnya merupakan penjelas bagaimana bentuk dari hubungan tersebut, menerangkan atau diterangkan. Sedangkan lambang "<-->" menerangkan bentuk hubungan dua arah. Untuk huruf " $C$ " menandakan kovarian, sedangkan "V" menandakan ragam.

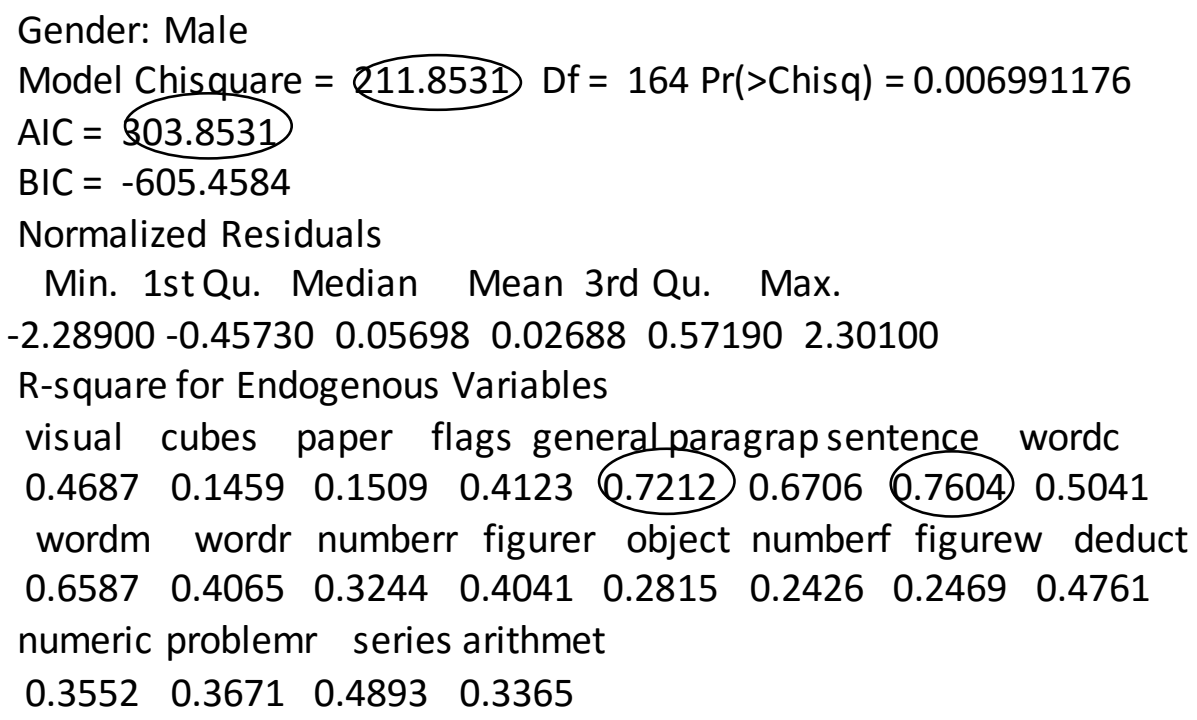

Untuk model persamaan struktural dalam kelompok gender "male" tidak jauh berbeda dengan "female", namun secara umum model ini dapat dikatakan sedikit lebih baik jika dilihat dari nilai AIC dan Chisquare, karena nilainya sedikit lebih kecil. Sedangkan jika dilihat besarnya keragaman peubah indikator dalam menerangkan peubah laten endogen justru lebih kecil, jika diambil nilai 70\% maka hanya ada dua peubah indikator yang memenuhi yaitu general dan sentence, dan ini masih sama peubah latennya yaitu verbal.

Parameter Estimates

lam[cubes:spatial].Male lam[paper:spatial].Male lam[flags:spatial].Male lam[paragrap:verbal].Male lam[sentence:verbal].Male lam[wordc:verbal].Male lam[wordm:verbal].Male lam[numberr:memory]. Male lam[figurer:memory].Male lam[object:memory].Male lam[numberf:memory].Male lam[figurew:memory].Male lam[numeric:math].Male lam[problemr:math].Male lam[series:math].Male lam[arithmet:math].Male V[spatial].Male
Estimate Std Error $z$ value $\operatorname{Pr}(>|z|)$ $0.41908750 .111942963 .7437591 .812872 \mathrm{e}-04$ $0.23555360 .061981063 .8004131 .444550 \mathrm{e}-04$ $\begin{array}{llll}1.3165245 & 0.23522255 & 5.596931 & 2.181790 \mathrm{e}-08\end{array}$ $0.25433350 .0212626311 .9615285 .651268 \mathrm{e}-33$ $0.40769110 .0309103713 .1894611 .009038 \mathrm{e}-39$ $0.37785620 .038985339 .6922683 .252265 \mathrm{e}-22$ $0.55870280 .0473617911 .7964874 .069484 \mathrm{e}-32$ $\begin{array}{lll}0.5763150 & 0.10751851 \quad 5.3601478 .315436 \mathrm{e}-08\end{array}$ $0.5726400 \quad 0.098709885 .8012436 .582505 \mathrm{e}-09$ $0.29945550 .059029425 .0729883 .916175 \mathrm{e}-07$ $0.28203490 .05903665 \quad 4.7772861 .776774 \mathrm{e}-06$ $0.24576200 .051080564 .8112631 .499794 \mathrm{e}-06$ $0.18753040 .029844696 .2835423 .309451 \mathrm{e}-10$ $\begin{array}{lllll}0.4193302 & 0.06575162 & 6.377489 & 1.800145 \mathrm{e}-10\end{array}$ $0.44114760 .06105327 \quad 7.2256184 .988281 \mathrm{e}-13$ $0.18786160 .030639846 .1312858 .717181 \mathrm{e}-10$ $21.08800525 .470181723 .8550831 .156903 \mathrm{e}-04$ 


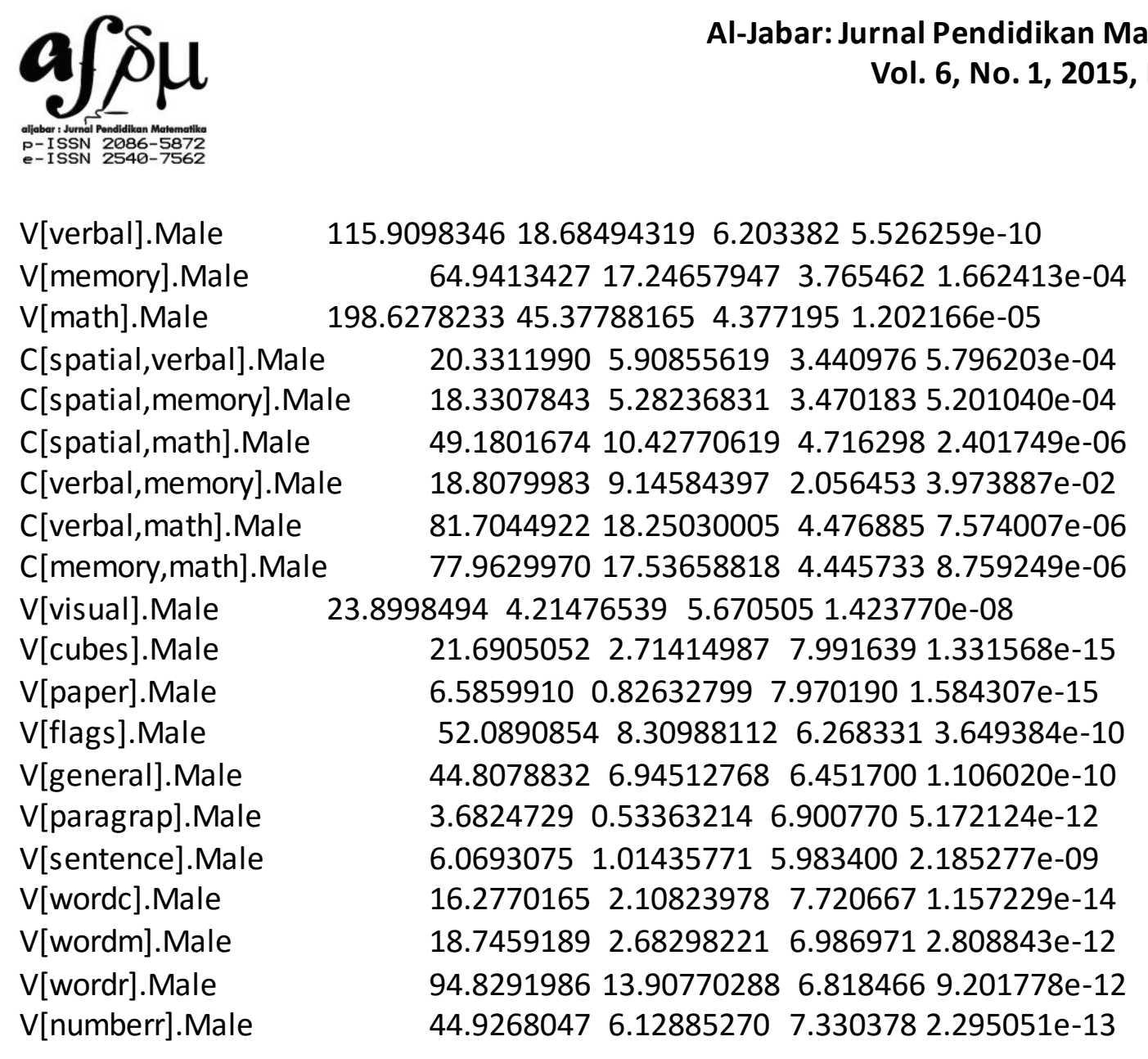

Untuk pendugaan nilai parameter koefisien juga tidak jauh berbeda dengan kelompok "female", yaitu memberikan nilai yang signifikan secara umum.

\section{SIMPULAN DAN SARAN}

Secara umum model yang dibangun memang belum sepenuhnya baik, hal ini terlihat dari besarnya Chi-square dan kecilnya nilai p-value. Hal ini bisa diperbaiki dengan mengurangi kompleksitas model, baik dengan membuang peubah-peubah yang tidak memiliki nilai signifikan maupun dengan mengurangi hubungan antar peubah

Dilihat dari R-square untuk peubah endogen, jika kita ambil nilai di atas $70 \%$ maka peubah yang sudah memenuhi besarnya keragaman tersebut adalah peubah yang merupakan indikator dari peubah "verbal" baik di kelompok "male" maupun "female". Berarti peubah "verbal" memang sudah baik dijelaskan oleh indikator-indikatornya dibanding peubah yang lain.

Jika dibandingkan model persamaan struktural secara kelompok, maka kelompok "male" memberikan model persamaan struktural yang lebih baik dibanding kelompok "female", ini terlihat dari besaran AIC dan Chisquare dimana nilainya lebih kecil.

\section{DAFTAR PUSTAKA}

Allison, P. (1999). Multiple Regression: A Primer. London Pine Forge Press.

Becker, R. A., Chambers, J. M., \&Wilks, A. R. (1988). The new S language: A programming environment for data analysis and graphics. Pacific Grove, CA: Wadsworth.

Bollen, K. A. (1989). Structural equations with latent variables. New York: Wiley. 
Chambers, J. M. (1998). Programming with data: A guide to the S language. New York: Springer.

Fox, J. (2006). Structural equation modeling with the sem package in r. Structural Equation Modeling, 13(3), 465-486.

Holzinger, K. J. and Swineford, F. A. (1939). A study in factor analysis: The stability of a bi factor solution. Supplementary Education Monographs, 48. University of Chicago.

Huang, B., Thornhill, N., Shah, S. and Shook, D (2002). Path analysis for process trobleshooting. Proceedings of Advanced Control of Industrial Process, Kumamoto, Japan, 10-12 Juni, 149-154. 